\title{
An Econometric Analysis of the Determinants of Electricity Supply in Nigeria
}

\author{
Peter Samuel Ubi (Corresponding author) \\ Department of Economics, University of Calabar, P. M. B. 1115, Nigeria \\ Tel: 234-80-3507-2890_E-mail: ubipetersamuel@yahoo.com \\ Lionel Effiom \\ Department of Economics, University of Calabar, Nigeria \\ Tel: 234-80-3088-7565_E-mail: leoeff2002@yahoo.com \\ Emmanuel O. Okon \\ Department of Economics, Salem University, Kogi State, Nigeria \\ Tel:234-80-3088-7565 E-mail: tonydom57@yahoo.com \\ Anagha Emiemu Oduneka \\ Department of Economics, University of Calabar, Nigeria
}

Received: December 14, 2011

doi:10.5430/ijba.v3n4p72

\author{
Accepted: December 27, 2011 \\ Published: July 15, 2012 \\ URL: http://dx.doi.org/10.5430/ijba.v3n4p72
}

\begin{abstract}
Electricity supply has been identified as the key constraint to industrialization and economic development in Nigeria. Recently, the government of Nigeria has initiated a lot of projects aimed at boosting electricity supply but this effort seems to yield no positive results. This may be attributed to the inability of policy makers to identify the determinants of electricity supply for actual policy formulation and implementation. Hence, this study analyzed the determinants of electricity supply in Nigeria (from 1970-2009), using a parametric econometric methodology of ordinary least squares. The results showed that technology, government funding, and the level of power loss were the statistically significant determinants of electricity supply in Nigeria and that an average of $40 \%$ of power is lost in transmission per annum. Thus, the government should inject more funds into the power sector to complete power projects with state of the art technology in order to enhance electricity supply.
\end{abstract}

Keywords: Econometric, Electricity supply, Technology, Price, Determinants, Industrialization, Parametric, Nigeria

\section{Introduction}

The Nigerian power sector is marked by low generating capacity relative to installed capacity and much of the country's citizens do not have access to uninterrupted supplies of electricity. At present electricity generation ranges from between 2 500 megawatts to about 3000 even with the inclusion of three gas-powered independent power projects in the Niger Delta region, while estimated national consumption is in excess of 10000 megawatts. Potential demand in the next few years is estimated at about 15,000megawatts. This is despite the fact that Nigeria is endowed with massive reserves of hydro energy, petroleum reserves and one of the largest gas reserve. Government policy for the sector during the 1980s and the 1990s and until recently did not properly anticipate national needs. For example, the last major electric installation in Nigeria was in 1990 when the Shiroro power station was commissioned. Since then no new units have come on stream and none of the existing ones have had a major overhaul for 15 years. The per capita consumption of electricity is $0.054 \mathrm{kw}$; only about $5 \%$ of our hydro electric capacity has been developed (Babatunde and Shuaibu, 2009). According to Iwayemi (2008), Nigeria's electricity crisis is striking for a variety of reasons. First is its occurrence despite the enormous endowments of non-renewable and renewable primary energy resources. The resource endowments of crude oil and natural gas currently estimated at 35 billion barrels and 185 trillion cubic feet, respectively, are more than adequate to 
fuel much of Sub-Saharan Africa (SSA) energy demand for several decades. Second is that coal reserves are also substantial at 2.75 billion metric tons. Also, large amount of renewable energy resources including hydro electricity, solar, wind and biomass energy are present. One of the many paradoxes in Nigeria is energy/electricity poverty amid plenty. Third, despite being a world ranking exporter of liquefied natural gas (LNG), Nigeria's gas-dominated electric grid experienced frequent collapse linked largely to inadequate gas supply. Gas pipeline vandalisation associated with resource control-linked militancy in the oil producing Niger Delta has compounded the supply problem. Huge gas flaring has been a regular feature of the Nigerian oil industry since production began in 1958. This wasteful gas flaring has consistently ranked Nigeria among the world's largest source of carbon emissions, a major factor in global warming. Fourth, the several billion dollars of public investment that went into generation and transmission capacity expansion in the past decades contrasts sharply with the extremely poor supply of electricity. Lastly, there are the high social, economic and environmental effects of poor public power supply and its extensive substitution with highly polluting generators. Empirical evidence suggests that Nigeria has one of the highest concentrations of generators globally.

Despite the recent unbundling of the power sub-sector in Nigeria, the situation has not changed for better. Previously, the state-owned Power Holding Company PLC dominated the power sector. The government has separated the power holding company into eleven distribution firms, six generating companies, and a transmission company, all of which will be privatized. Several problems, including union opposition, have delayed the privatization. Available statistics show that only 40 percent of the population has electricity, majority of who are concentrated in urban areas. According to Ali-Akpajiak and Pyke (2003), the distribution of electricity shows great disparities between rural and urban, and between residential and industrial areas in the urban centres. They went further to state that based on 1998 data, the states of Jigawa, kebbi, Sokoto, Katsina, Taraba, Yobe, Borno, Bauchi, Adamawa, Akwa Ibom, Cross River and Benue were classified as energy-poor states, while the energy- rich states were Edo, Kwara, Ogun and Oyo with electricity accessible to more than 60 per cent of the people. In Lagos, more than 90 per cent of the populace had access to electricity. Kaduna, Kano and Rivers were not covered in the exercise. Ali -Akpajiak and pyke,(2003) further observed that although these figures might have changed, the pattern remains the same. In fact, the electricity sector is in crisis. This crisis is exampled by such indicators as electricity blackouts and persistent reliance on self generating electricity. Indeed, Nigeria is running a generator economy with its adverse effect on cost of production. The country's electricity market is dominated on the supply side by a state owned monopoly - Power Holding Company of Nigeria (PHCN) formerly called the National Electric Power Authority (NEPA) which has been incapable of providing minimum acceptable international standards of electricity service that is reliable, accessible and available for the past decades (Ekpo, 2009, Udah, 2010).

In the same vein, Iwayemi (1991and 2008) noted that although the nominal average generation capacity of Power Holding Company of Nigeria (PHCN) is on the average 4550 megawatt (installed capacity a at this period was 7 $011 \mathrm{MW}$ ) which exceeds the average peak load demand of about 2000 megawatt; transmission and distribution bottlenecks have created a notorious gap between demand requirements and the delivered electricity. A major factor in this poor performance is the distortion in the investment pattern in the industry which has focused more on generation to the detriment of transmission and more especially distribution facilities which have lagged abysmally behind, resulting in a devastating impact on the industrial environment. More so; there is the problem of corruption, hydrological inadequacies in hydro electric plants, particularly within the dry season and the vandalization of electricity equipment which has resulted to frequent breakdown of the electricity transmission lines and loss of large quantity of electric power annually (Ayodele, 1998, Okafor, 2008). Given the above scenario, it is not surprising that World Bank report (1995) rates Nigeria as the worst performer in the power sector out of 20 developing nations. The rating shows Nigeria as having the highest percentage system loss; lowest generation capacity factor and average collected revenue as well as lowest return on investment. The report further notes that successive governments in Nigeria have been inclined towards political rather than economically motivated investment in the energy sector. Thus, they have failed to promote economic growth but have rather incurred excessive indebtedness. Undoubtedly, Nigeria's electricity supply crisis significantly undermined the effort to achieve sustained economic growth, competitiveness in regional and global markets, employment generation and poverty alleviation.

Against this backdrop, the major research issue to be addressed by this paper is: what are the key determinants of electricity supply in Nigeria. Interestingly, so much has been written on poor electricity supply in Nigeria and a number of factors have been identified as being responsible for the poor electricity supply (see Ayodele, 2001; Adegbulugbe and Akinbami, 2002, Isola, 2007 and Iwayemi 2008) - ranging from poor funding to corruption but no study has actually carried out a parametric analysis of the determinants to show the extent to which these determinants constrain electricity supply in Nigeria. Ogbuagu, Ubi and Effiom (2010) attempted an analysis of the factors affecting electricity supply in Nigeria using ordinary least squares without any econometric tests of the time series properties of the data. It is widely 
acknowledged that such analysis leads to spurious and nonsensical results. This paper therefore seeks not only to contribute to the discussion on poor electricity supply in Nigeria but also to identify and analyze the determinants of electricity supply using contemporary parametric econometric techniques. On the basis of the evidence from these parametric econometric estimations, conclusions would be drawn on the relative relevance of the determinants of electricity supply in Nigeria for policy-making purposes. This paper comprises of six sections. Section 1 is the introduction; in section 2, an attempt is made to provide an historical overview of the electricity sector in Nigeria. Empirical and theoretical issues formed the focus of section 3. Section 4 builds the model and throws more light on the scope of the study, method of data analysis and the sources of the numerical data. Section 5 discussed the implications of the empirical results while section 6 concludes the paper with policy implications.

\section{An Historical Overview of Electricity Sector in Nigeria}

According to Isola (2007), an historical scrutiny of the electricity sector in Nigeria will reveal a movement from a fragmented ownership of generating plants involving some monopolistic competition to one of unified ownership and control by government fiat, involving virtually absolute monopoly. The ongoing reforms in the nation's power sector which started in 2005 thus constitute a U-turn or policy reversal for the sector. Gross inefficiency in the sector, the heavy dependence on government treasury, rapid technological development and trends in the management of electricity sectors of other countries were the major motivating factors for the reforms.

Between the time electricity was introduced to Nigeria and the time federal government embarked on reform, three main periods are discernable. First, the period that predated the establishment of the Electricity Corporation of Nigeria (ECN) in 1951. That was a period of isolated generation facilities with low rates of electrification. Electricity supply in Nigeria was confined to a few urban areas and to mining centres. The first electricity generation plants was installed at Ijora, Lagos, in 1898. This was undertaken by the then colonial government under the jurisdiction of the Public Works Department. Later, other electricity undertakings were set up by the native and municipal authorities in different parts of Nigeria. In 1925, a privately owned company, the Nigeria Electricity Supply Company (NESCO), commenced the generation of electricity using a 2MW hydroelectric dam at Kurra falls, near Jos. Similarly, the African Timber and Plywood Limited started to operate its plants at Sapele in 1930, while Shell Development Company of Nigeria equally operated at Bonny and Delta areas in 1942.

By 1950, the need for co-ordination and integration of the operating plants was considered necessary. In response to that necessity, the colonial government established the Electricity Corporation of Nigeria (ECN) through Ordinance No. 15 of 1950. This ordinance brought under one umbrella all the electricity undertakings owned and controlled by the native and municipal authorities under the Public Works Department. The powers and functions of the ECN were set out in sections 21, 29, 30, and 50 of the 1950 Ordinance. An examination of the provisions revealed that the ECN was charged with the responsibilities of electric power generation, transmission and distribution and sales throughout Nigeria. Besides, ECN was granted the power to acquire, hold and dispose off lands for purposes of effective operation and actualization of the objectives of regular power supply.

At completion of the Niger Dam Hydroelectric project at Kanji in 1962, the Niger Dam Authority (NDA) was established; a parallel electricity body came into existence. The Niger Dam Authority was of mandated to oversea the development of hydro electric facilities in Nigeria. The enabling Act charged NDA with the responsibility for constructing and maintaining dams and other projects on the river Niger and elsewhere in Nigeria. Its functions also included generating electricity by means of water power, improving navigation and promoting fisheries and irrigation. It is also useful to add that the ECN initiated the construction of Jebba and Shiroro hydro projects.

Based on the then prevalent buck passing between ECN and NDA on intermittent power failure in Nigeria, the federal government decided to merge the two organizations into one body. To accomplish this task, the federal government appointed a Canadian firm of consultants to look into the technical details of the merger in 1971. The reports submitted by the consultants, induced the federal government to establish the National Electric Power Authority (NEPA) through the amalgamation of ECN and NDA. Decree No. 24 of 1972 gave the necessary legal backing. The decree mandated NEPA to maintain an efficient, co-ordinated and economic system of electricity supply for all parts of the federation. NEPA thus became a government monopoly, responsible for the production, transmission and distribution of electricity to final consumers. It generated electricity from the following power stations:
A Ijora Thermal Power Station
- $\quad$ Established In 1956
B Afam Thermal Power Station
- $\quad$ Established In 1962
C Delta Thermal Power Station
- $\quad$ Established In 1966
D Kanji Hydro Power Station
- $\quad$ Established In 1968 
E Ogorode Thermal Power Station

F Jebba Hydro Power Station

G Lagos Thermal Power Station

H Shiroro Hydro Power Station
- $\quad$ Established In 1980

- $\quad$ Established in 1985

- $\quad$ Established in 1986

- $\quad$ Established in 1989

All the power stations, distribution stations and substations were specially interlinked by a transmission network, the national grid. The whole output of electricity generated nationwide was collected in a pool at the national control centre, Osogbo. From there, the electricity generated was redistributed to all parts of the federation. In order to obtain smooth transmission of the electricity generatrd at the different power stations, NEPA put in place a total of 11000 kilometres of transmission lines nationwide. In the same vein, extensive distribution of transformers and other relevant facilities were installed to ensure an even distribution of electricity to all customers across the federation.

It is noteworthy that government monopoly of the power sector in Nigeria has left behind some problems that have far reaching implications for regular supply of electricity in Nigeria (Isola, 2007).

\section{Empirical and Theoretical Issues on the Determinants of Electricity Supply}

The installed capacity of electricity by PHCN (formerly NEPA) rose steadily between 1970 and 1989 . The average yearly rate of growth was 13 per cent. Thereafter, the trend with respect to installed capacity stagnated for the remaining part of the $20^{\text {th }}$ and $21^{\text {st }}$ century. This confirms the fact that investment in electricity capacity was almost zero during 1990 and 1999 (Imoke, 2004). This clearly shows that underutilization of capacity hampered electricity generation vis-à-vis supply. According to Imoke (2004), actually daily generation fell to less than 2,000 MW by 1999, although the installed power generation capacity was $6136 \mathrm{MW}$. As at May, 1999, actual generation stood at $1700 \mathrm{MW}$ and a peak of 2410 MW was recorded by December, 2004. This low generation vis-à-vis supply was largely traceable to the lack of routine and turnaround maintenance of power stations between 1990 and 1999. Only 19 out of 79 generating units were in operation in 1999 (Imoke, 2004, Isola, 2007). These factors worsened electricity supply in the face of ever increasing demand despite the level of attention given to the energy sector since the inception of the Obasanjo administration of 1999-2007.

Besides, Iwayemi (2008), Okafor (2008) attributed the legendary poor supply of electricity in Nigeria to high levels of power and revenue losses, both technical and non-technical. Technical losses are those associated with the transmission and distribution of power which can be reduced through injection of funds into the power sector to overhaul the transmission and distribution network(s). On the other hand, non-technical losses primarily occur due to electricity being stolen by tapping into transformers or directly from low-voltage power lines. Average transmission and distribution losses between 1990-2009 had increased to 40 per cent against 27 per cent in 1970 to 1989. And between 2001 till date, the situation has not changed (see Table 1 in appendix).

The energy mix in the generation of electricity is another major issue. Nigeria has abundant reserves of primary energy that can be harnessed for power generation. These include oil, natural gas, coal and hydro. Currently, the technology in generation of electricity is biased in favour of natural gas, which accounts over 57 per cent of total fuel. This has caused some in-built problems for the sustainable growth and development of the power sector. Apart from underdeveloping and underutilizing other sources of energy like coal or hydro as a result of poor technology, natural gas is inefficiently used for generating electricity in Nigeria due to government subsidy (Iwayemi, 2001, Isola, 2007).

Also, PHCN's tariff's structure (that is the price structure) has always been below the marginal cost, a situation that has worsened PHCN's financial position (Isola, 2007). The average price of electricity was 60 kobo per kilowatt and rose to 4.00 naira per kilowatt in 1990. However, the privatization and commercialization decree of 1988 recognized the need for PHCN to operate a tariff structure that facilitated increased revenue generation which would reduce its dependence on government funding. Consequently, the government allowed PHCN to review its tariff upward in consultation with the Utilities Charges Commission. Further upward review may be inevitable in order to get the price right (Nnanna, Alade, Odoko, 2003). To compound these problems in the Nigerian electricity sector is the problem of hydrological inadequacies in hydro electric plants, particularly within the period of dry season. The vandalisation of electricity equipment in several points in the country does not seem to help matters. All of these have culminated in frequent breakdown of electricity supply.

From the analysis, it is very obvious that the elementary theory of supply is the basic theoretical framework which underlies this research. It should be noted that supply as used here does not necessarily mean the total stock of a product produced but it is just the amount that is actually offered for sale. It is a common knowledge that producers tend to offer more for sale at a higher price and less at a lower price, all things being equal. But given the peculiarity of electricity 
product in Nigeria and the fact that it is produced by a monopoly firm enjoying the advantages inherent in a monopolistic market structure, the law of supply as stated above may not necessarily apply. In line with the theory of supply, there are factors that determine the quantity of a product that may be offered for sale at any given price. These factors are price of the commodity, cost of production, state of technology, natural phenomenon like rainfall, government policy, etc to mention but a few. From the literature review, it can be deduced that the determinants of electricity supply in Nigeria are but not limited to price, government funding, power loss, technology and rainfall. It should be noted that these factors to a greater extent determine the quantity (may be quality also) and regularity of electricity offered for sale by the electricity organization in Nigeria. It is on the basis of these factors that affect electricity supply in Nigeria that we adopt a baseline model specification for this study.

\section{The Model and Data}

The period of analysis covers 1970-2009. This is the longest period for which numerical data is available and accessible. The econometric approach is based on a time series data regression. The model specification is consistent with the literature and the supply theory reviewed which allows for the identification of the determinants of electricity supply in Nigeria. The model specification also follows that of Subair and Oke (2008) except that our focus is on the determinants of electricity supply in Nigeria and not privatization. Following the estimation of the long run coefficients, the paper proceeds to estimate the error correction model. The paper adopts the general to specific approach to arrive at the parsimonious estimate by eliminating jointly insignificant variables. The error correction term shows the speed of adjustment to restore equilibrium in the dynamic model. In particular, the ECM coefficients show quickly variables converge to equilibrium and the ECM term is expected to have a negative sign (Udah, 2010). Thus the model is:

$$
\mathrm{ES}=\mathrm{f}(\mathrm{P}, \mathrm{GF}, \mathrm{RF}, \mathrm{TECH}, \mathrm{PWL})
$$

Where:

$\begin{array}{ll}\mathrm{ES} & =\text { Electricity supply in Megawatts hours } \\ \mathrm{P} & =\text { Price of electricity per Megawatt in naira and kobo } \\ \mathrm{GF} & =\text { Government funding (in naira) of electricity in Nigeria } \\ \mathrm{RF} & =\text { Quantity of rainfall per year in cubic centimeters } \\ \mathrm{TECH} & =\text { The state of technology (time variable, one year is one data point) } \\ \mathrm{PWL} & =\text { quantity of electricity or power lost per year in Megawatts }\end{array}$

The function above simply states that electricity supply is a function of price per megawatt hours, government funding, rainfall, technology and the quantity of power or electricity loss. But this function can be transformed into an econometric form as:

$$
\mathrm{ES}_{\mathrm{t}} \quad=\quad \mathrm{a}_{0}+\mathrm{a}_{1} \mathrm{Pt}+\mathrm{a}_{2} \operatorname{lnGF} \mathrm{t}_{\mathrm{t}}+\mathrm{a}_{3} \operatorname{lnRF_{\mathrm {t}}}+\mathrm{a}_{4} \operatorname{lnTECH}_{\mathrm{t}}+\mathrm{a}_{5} \operatorname{lnPWL} \mathrm{L}_{\mathrm{t}}+\mathrm{u}
$$

Where:

$\mathrm{ES}_{\mathrm{t}}=$ Electricity supply in Megawatts hours at time $\mathrm{t}$

$\mathrm{P}_{\mathrm{t}} \quad=\quad$ Price of electricity per Megawatt in naira and kobo at time $\mathrm{t}$

$\mathrm{GF}_{\mathrm{t}}=$ Government funding (in naira) of electricity in Nigeria at time $\mathrm{t}$

$\mathrm{RF}_{\mathrm{t}} \quad=\quad$ Quantity of rainfall per year at time $\mathrm{t}$

$\mathrm{TECH}_{\mathrm{t}}=$ The state of technology at time $\mathrm{t}$ (time variable, one year is one data point)

$\mathrm{PWL}_{\mathrm{t}}=$ quantity of electricity or power lost per year in Megawatts at time $\mathrm{t}$

$\mathrm{U}=$ the error tem

$\ln \quad=\log$

$\mathrm{a}_{0}-\mathrm{a}_{5}=$ Parameters to be estimated (representing the co-efficient of the explanatory variables)

In accordance with the literature reviewed earlier, price of electricity per megawatt is expected to have a positive effect on electricity supply. This is because if PHCN operates a tariff structure (price structure) that facilitates increased revenue generation it would enable the institution reinvest in the state of the art transmission and distribution technology which will boost electricity supply.

It is also argued that increased government funding of the electricity sector would boost the capacity of the institution to normalize electricity supply. Thus, government funding is expected to have a positive effect on electricity supply in 
Nigeria. In the same vein, increased rainfall is expected to have a positive effect on electricity supply, especially electricity supply from hydro power stations. Isola (2007) emphasized that improvement in transmission and distribution technology would affect electricity supply positively. Iwayemi (2001) had asserted emphatically that one of the basic problems of electricity supply in Nigeria is the high level of technical losses (that is losses associated with the transmission and distribution of power). The higher the level of power lost in transmission and distribution, the lower the electricity supply, ceteris paribus and vice-versa. Thus, a negative relationship is expected between electricity supply and power loss variable.

A time series data set was obtained from different sources. The data on electricity supply, rainfall and power loss were obtained from the Central Bank Statistical bulletin, (2009). The data on price (tariff) of electricity were obtained from the annual technical reports of PHCN, (2009). The numerical data on government funding was sourced from Agagu (2002) and Imoke (2004) and annual technical reports of PHCN, (2009). It should be noted that the periods 1970 to 1989 marked the increase in electricity tariff from 60 kobo to N4.00 naira in 1990 to 2009 and N5.00 in 2010. As already stated, technology variable is proxied by chronological time. The power loss variable is calculated by subtracting electricity supplied from "electricity generated" in each year. The result would give an insight into the trend or level of electricity or power lost in every year and over the years (CBN statistical bulletin, 2009).

\section{Empirical Results}

The first step involved in the estimation of a linear relationship is the comprehensive pre-testing procedure to investigate the characteristics of the time series variables. The pre-testing procedure and the regression results are analyzed below.

Using the augmented Dickey-Fuller tests, the results as presented in Table 2 (see appendix) has shown that only Power loss (PWL), technology (TECH) are stationary at the level while other series (variables) are stationary at first difference. That is, the result indicates that the variable, PWL and TECH are integrated of order zero - 1(0) while other variables ES, P, RF, and GF are integrated of order one - 1(1).Therefore, a co-integration test was carried out to confirm and determine the existence of a long-run relationship among the variables in the equation.

The Johansen Cointegration test reveals that there is a long-run equilibrium relationship between electricity supply and other variables captured in the model. The results indicate one cointegrating equation(s) at 5 per cent significance level. The conclusion drawn from this result is that there exists a unique long-run relationship between LOG(ES), LOG(GF), P, LOG( PWL), LOG(RF) and LOG(TECH). Since there is one cointegrating vector, an economic interpretation of the long-run on electricity supply in Nigeria can be obtained by normalizing the estimates of the unconstrained cointegating vector on electricity supply. The identified cointegrating equations can then be used as an error correction term (ECM) in the error correction model. This series will form the error correction variable, similar to the residuals generated when using the Engle-Granger two-stage method (See Table 3 in appendix).

The result of the over-parameterized model reveals that most of the coefficients of the variables have the right sign and conform to economic theoretical expectations. However, the concern of this study is in the parsimonious result where insignificant variables were eliminated to allow for a more interpretable dynamic result (see appendix, Table 4)

From Table 5 (see appendix), power loss (PWL) and its lagged values are negative and in conformity with economic theoretical expectation. This implies that an increase in the level of electricity loss will reduce electricity supply in Nigeria, ceteris paribus. Specifically, the coefficient of current electricity loss shows that an increase in the level of electricity loss by 1 per cent would lead to a 0.055607 per cent decrease in electricity supply (ES), all things being equal. Only the current level of electricity or power loss (PWL) is statistically significant at 5 per cent level.

Also, the lagged value of government funding (GF(-2) is positive and conforms with economic theory. This implies that if government funding increases by 1 per cent, electricity supply will increase by 0.011023 per cent, ceteris paribus. The coefficient of government funding is statistically significant at 5 per cent level.

The current value of price $(\mathrm{P})$ is positive and in line with theoretical expectation. This means that if the current year's price increases by 1 per cent, the current level of electricity supply will increase by 0.003664 per cent, ceteris paribus. However, the coefficient of the current value of price is not statistically significant at 5 per cent level. This result is at variance with that obtained by Ogbuagu, Ubi and Effiom, (2010) whose analysis did not test the time series properties of the data used. This implies that price does not have a reliable influence on electricity supply in Nigeria. This, perhaps may be due to some reasons; firstly, it may be due to the fact that electricity is supplied by a public company owned by government in which profit making is not its cardinal goal, thus price is not a critical factor in determining electricity supply. On the other hand, it may be due to the fact that electricity is under-priced thus making price not to be a determining factor that affects its supply in Nigeria. 
The current value of technology and its lagged values are positive, statistically significant at 5 per cent level and in line with economic theoretical expectation. The implication of this result is that a 1 per cent increase in the current level of technology and in its lagged values will increase the current level of electricity supply in Nigeria by 30.34707 per cent, 20.14408 per cent, and 19.65774 per cent respectively, ceteris paribus. This implies that technology is a critical factor in electricity supply in Nigeria and therefore deserves policy attention. This result agrees with Isola, (2007), Iwayemi, (2008) who had identified technology as a critical determinant of electricity supply in Nigeria.

In the same vein, the level of last year's electricity supply (ES(-1) affects positively the current level of electricity supply in Nigeria. A one per cent increase in last year's electricity supply would lead to 0.6800 per cent increase in the current year electricity supply, all things being equal. This variable is significant at 5 per cent level

The coefficient of determination, the adjusted $\mathrm{R}^{2}$ with 0.80 shows that about 80 per cent variation in electricity supply is determined by changes in the explanatory variables. Thus, it is a good fit. The F-statistic as shown in Table 5 indicates that all the variables are jointly statistically significant at 5 per cent level.

The Durbin-Watson statistic (D.W) of 2.0 reveals no autocorrelation in the models. Hence, the result is good for econometric analysis. The coefficient of the error correction term carries the correct sign and it is statistically significant at 5 per cent level with the speed of convergence to equilibrium of 75 per cent.

\section{Conclusion and Policy Implications}

This study analyzed the joint interaction of the determinants of electricity supply in Nigeria. The study applied the contemporary econometric methods of stationarity test, cointegration test and ordinary least squares. One strong outcome of the study is that the level of power loss, government funding and technology are the most reliable determinants of electricity supply in Nigeria.

Although the root causes of electricity supply inadequacy in Nigeria are not completely unfolded in this research, it may as well serve as a basis for formulating policies to tackle electricity supply problems in Nigeria. Hence, rational policy recommendations to tackle electricity supply problem in Nigeria require that more funds/subventions by government should be injected into the power sector in order to swiftly complete the various power projects with state of the art technology. The funding/investment in the state of the art technology in transmission and distribution of electricity will ultimately reduce power loss, manage consumption expansion crisis (reduce congestion) and boost electricity supply even in the face of an ever increasing population in Nigeria. The government should as a follow up to improvement in technology, also put adequate security in place to protect electricity generation, transmission and distribution equipments from being vandalized. Efficient supply management measures (rationing) should be put in place in the face of higher level of power loss or to cater for electricity consumption expansion crisis as this would ultimately slightly stabilize electricity supply. From the study it is discovered that price is not a significant variable that affects electricity supply in Nigeria. This (as earlier explained) may be due to the fact that electricity is under-priced in Nigeria. It demands that an appropriate pricing policy be formulated and implemented as this may boost electricity supply in Nigeria.

\section{References}

Adegbulugbe, A., \& Akinbami, J. (2002). Policy options for the attainment of sustainable electricity supply in Nigeria. Central Bank of Nigeria Bullion, 26(4), 3-12.

Ali-Akpajiak, S. E., \& Pyke, M. T. (2003). Poverty in Nigeria. Abuja: Oxfam Publications, (Chapter 10).

Ayodele, A. S. (1998). Energy crisis in Nigeria: The case of Electric energy Market. Central Bank of Nigeria Bullion, 22(4), 22-50.

Ayodele, A. S. (2001). Improving and sustaining power (electricity) supply for socio-economic development in Ngeria. [Online] Available: http://www. cenbank.org/out/annual/ACZRU/ 2001 (May 12, 2009)

Babatunde, Adetunji, \& Shuaibu, Isa. (2009). The demand for residential electricity in Nigeria. A bound testing approach. [Online] Available: http://www.africametrics.org/documents/conference09/papers/Babatunde_Shuaibu.pdf (August 6, 2011)

CBN. (2009). Statisitical Bulletin (December), Vol. 21. Abuja: A publication of Central Bank of Nigeria, (Chapter 12)

Ekpo, A. H. (2009). The global Economic crisis and the crisis in the Nigerian Economy, Presidential address to the $50^{\text {th }}$ conference of the Nigerian Economic Society, September $8^{\text {th }}$, Abuja, Nigeria.

Imoke, Liyel. (2004). The power sector: Catalyst for Economic growth and development. A paper presented by the Hon. Minister for Power and Steel and chairman of NEPA Technical committee at an interactive forum with President Olusegun Obasanjo on October $14^{\text {th }}$. 
Isola, W. A. (2007). Developments in the Nigerian Electricity Sector. A paper presented at the $50^{\text {th }}$ anniversary of the Nigerian Economic Society, September $8^{\text {th }}$, Abuja, Nigeria.

Iwayemi, Akin. (2008). Investment in electricity generation and transmission in Nigeria: Issues and Options.Being a paper presented in the first quarter of 2008 in a summit organized by the International Association for Energy Economics, Ibadan, Nigeria.

Iwayemi, A. (1991). Deregulation of public utilities in Nigeria: An econometric analysis. In CEAR (Ed.), Analysis of key public sector utilities in Nigeria (pp. 55-98) Ibadan: University of Ibadan Press.

Iwayemi, P. A. (2001). Nigeria's fractured Development: The energy connection. Inaugural Lecture delivered at the University of Ibadan, $11^{\text {th }}$ January.

Nnanna, J. O., Alade, S. O., \& Odoko, F. O. (2003). Contemporary Economic policy Issues in Nigeria. Abuja: A publication of Central Bank of Nigeria, Chapter 3.

Ogbuagu, Uchechi, Ubi, Peter, \& Effiom, Lionel. (2010). The structure of electricity supply in Nigeria. The Leajon, An academic journal of interdisciplinary studies, 2(1), 42-48.

Okafor, E. O. (2008). Development Crisis of the Power supply and Implications for Industrial sector in Nigeria. Kamla-Raj Journal, 6, 83-92.

Subair, Kola, \& Oke, David. (2008). Privatization and trends of aggregate consumption of Electricity in Nigeria: An empirical analysis. African Journal of Accounting, Economics, Finance and Banking research, 3(3), 18-27.

Udah, Enang B. (2010). Industrial Development, Electricity Crisis and Economic performance in Nigeria. Europeanjournal of Economics, Finance and Administrative Sciences. 105-121. [Online] Available: http://www.eurojournals.com (August 6, 2011).

World Bank. (1995). Energy sector management assistance programme report on Nigeria. Washington D. C.: World Bank.

Table 1. Electricity generation and supply balance sheet, 2008

\begin{tabular}{|c|c|c|c|c|}
\hline & $\begin{array}{c}\text { ELECTRICITY } \\
\text { GENERATION IN } \\
\text { YEAR }\end{array}$ & $\begin{array}{c}\text { ELECTRICITY SUPPLY IN } \\
\text { MW }\end{array}$ & $\begin{array}{c}\text { POWER LOSS IN } \\
\text { TRANSMISSION IN } \\
\text { MW }\end{array}$ & $\begin{array}{c}\text { PERCENTAGE } \\
\text { OF POWER LOSS }\end{array}$ \\
\hline 1970 & 176.6 & 145.3 & 31.3 & 17.7 \\
\hline 1971 & 215.4 & 181.1 & 34.3 & 15.9 \\
\hline 1972 & 255.4 & 211.1 & 44.3 & 17.3 \\
\hline 1973 & 299.7 & 232.7 & 67 & 22.4 \\
\hline 1974 & 261.1 & 266.2 & -5.1 & -1.9 \\
\hline 1975 & 395.4 & 318.7 & 76.7 & 19.3 \\
\hline 1976 & 468.7 & 369.6 & 99.1 & 1.1 \\
\hline 1977 & 538 & 435.7 & 102.3 & 3.5 \\
\hline 1978 & 522.7 & 504.4 & 250.6 & 35.3 \\
\hline 1979 & 710.7 & 460.1 & 278.2 & 62.2 \\
\hline 1980 & 815.1 & 536.9 & 551.8 & 29.6 \\
\hline 1981 & 887.7 & 335.9 & 288.3 & 29.9 \\
\hline 1982 & 973.9 & 685.6 & 297.9 & 39.0 \\
\hline 1983 & 994.6 & 696.7 & 400 & 38.5 \\
\hline 1984 & 1025.5 & 625.50 & 449.4 & 31.5 \\
\hline 1985 & 1166.8 & 717.40 & 387.1 & 33.8 \\
\hline 1986 & 1228.9 & 841.80 & 433.1 & 35.8 \\
\hline 1987 & 1286 & 852.90 & 476.9 & 41.5 \\
\hline 1988 & 1330.4 & 853.50 & 638.4 & \\
\hline 1989 & 1462.7 & 976.60 & & \\
\hline 1990 & 1536.9 & 898.50 & & \\
\hline
\end{tabular}




\begin{tabular}{|l|c|c|c|c|}
\hline 1991 & 1617.2 & 946.60 & 670.6 & 41.5 \\
\hline 1992 & 1693.4 & 993.00 & 700.4 & 41.1 \\
\hline 1993 & 1655.8 & $1,141.40$ & 514.4 & 31.1 \\
\hline 1994 & 1772.9 & $1,115.00$ & 657.9 & 37.1 \\
\hline 1995 & 1810.1 & $1,050.90$ & 759.2 & 41.9 \\
\hline 1996 & 1854.2 & $1,033.30$ & 820.9 & 44.3 \\
\hline 1997 & 1839.8 & $1,009.60$ & 830.2 & 45.1 \\
\hline 1998 & 1724.9 & 972.80 & 752.1 & 43.6 \\
\hline 1999 & 1859.8 & 883.70 & 976.1 & 52.5 \\
\hline 2000 & 1738.3 & $1,017.30$ & 721 & 41.5 \\
\hline 2001 & 1689.9 & $1,104.70$ & 585.2 & 34.6 \\
\hline 2002 & 2237.3 & $1,271.60$ & 965.7 & 43.2 \\
\hline 2003 & 6180 & $1,519.50$ & 4660.5 & 28.5 \\
\hline 2004 & 2763.6 & $1,825.80$ & 937.8 & 33.9 \\
\hline 2005 & 2779.3 & $1,873.10$ & 906.2 & 32.6 \\
\hline 2006 & $2771.5^{*}$ & $1,739.47^{*}$ & 1031.9 & 37.2 \\
\hline 2007 & $2775.4^{*}$ & $1,812.79^{*}$ & 962.6 & 34.7 \\
\hline 2008 & $2773.4^{*}$ & $1,808.45^{*}$ & 964.9 & 34.8 \\
\hline
\end{tabular}

Source: CBN 2009. Columns 4 and 5 are computed by the Author.

Table 2. Unit root test-Augmented Dickey Fuller unit root test

\begin{tabular}{|c|c|c|c|c|c|}
\hline Variables & \multicolumn{2}{|c|}{ ADF Statistics(Computed) } & \multicolumn{2}{|c|}{$5 \%$ Critical Value } & Remark \\
\hline & Level & $1^{\text {st }}$ Difference & Level & $1^{\text {st }}$ difference & \\
\hline Ln(ES) & -0.152036 & -4.051919 & -2.9422 & -2.9446 & $1(1)$ \\
$P$ & -0.944444 & -4.242641 & -2.9422 & -2.9446 & $1(1)$ \\
Ln(RF) & -0.350469 & -3.986086 & -2.9422 & -2.9446 & $1(1)$ \\
Ln(GF) & 2.034782 & -3.899026 & -2.9422 & -2.9446 & $1(1)$ \\
$\ln (\mathrm{TECH})$ & -3.237523 & - & -2.9422 & -2.9446 & $1(0)$ \\
$\ln (\mathrm{PWL})$ & -3.003981 & - & -2.9422 & -2.9446 & $1(0)$ \\
\hline
\end{tabular}

Source: Computed by the author.

$* * \ln =\log$.

Table 3. Cointegration test-Johansen cointegration test for the electricity supply equation

\begin{tabular}{|c|c|c|c|l|}
\hline & Likelihood & 5 Percent & 1 Percent & \multicolumn{1}{|c|}{ Hypothesized } \\
\hline Eigenvalue & Ratio & Critical Value & Critical Value & \multicolumn{1}{|c|}{ No. of CE(s) } \\
\hline 0.766752 & 85.62095 & 68.52 & 76.07 & None ** \\
\hline 0.576337 & 40.49576 & 47.21 & 54.46 & At most 1 \\
\hline 0.220562 & 13.87241 & 29.68 & 35.65 & At most 2 \\
\hline 0.173975 & 6.147769 & 15.41 & 20.04 & At most 3 \\
\hline 0.007159 & 0.222734 & 3.76 & 6.65 & At most 4 \\
\hline
\end{tabular}

$*(* *)$ denotes rejection of the hypothesis at $5 \%(1 \%)$ significance level

L.R. test indicates 1 cointegrating equation(s) at $5 \%$ significance level

Unrestricted Cointegration Rank Test

Source: Author's computation. 
Table 4. Result of the over-parameterized model

\begin{tabular}{|c|c|c|c|c|}
\hline \multicolumn{5}{|c|}{ Dependent Variable: LOG(ES) } \\
\hline Variable & Coefficient & Std. Error & t-Statistic & Prob. \\
\hline $\operatorname{DLnES}(-1)$ & 0.209563 & 0.247406 & 2.847043 & 0.0123 \\
\hline $\operatorname{DLnES}(-2)$ & 0.437747 & 0.238099 & 1.838506 & 0.0889 \\
\hline DP & 0.001762 & 0.003756 & -1.970965 & 0.0168 \\
\hline $\mathrm{DP}(-1)$ & 0.000327 & 0.004601 & 0.469045 & 0.6245 \\
\hline $\mathrm{DP}(-2)$ & -0.004063 & 0.004281 & -0.949129 & 0.3599 \\
\hline LnTECH & 23.20314 & 30.55800 & 2.934788 & 0.0080 \\
\hline LnTECH(-1) & 33.42367 & 19.61873 & -2.672140 & 0.0035 \\
\hline LnTECH(-2) & 14.43495 & 21.55801 & 2.787641 & 0.0235 \\
\hline DLnGF & 0.039182 & 0.036058 & -1.086660 & 0.2969 \\
\hline $\operatorname{DLnGF}(-1)$ & 0.006638 & 0.039574 & 0.167740 & 0.8694 \\
\hline $\operatorname{DLnGF}(-2)$ & 0.014267 & 0.036344 & 2.117396 & 0.0083 \\
\hline DLnRF & 0.091812 & 0.162972 & 0.563361 & 0.5828 \\
\hline $\operatorname{DLnRF}(-1)$ & 0.085174 & 0.310980 & 0.273888 & 0.7885 \\
\hline $\operatorname{DLnRF}(-2)$ & 0.096589 & 0.335517 & 0.287880 & 0.7780 \\
\hline LnPWL & -0.060674 & 0.060280 & -4.006546 & 0.0005 \\
\hline LnPWL(-1) & -0.080272 & 0.065764 & 2.220623 & 0.0439 \\
\hline LnPWL(-2) & -0.025887 & 0.071874 & -2.360175 & 0.0045 \\
\hline $\operatorname{ECM}(-1)$ & -0.883719 & 0.000570 & 3.173366 & 0.0050 \\
\hline $\mathrm{C}$ & 1.196790 & 1.153453 & 1.037572 & 0.3184 \\
\hline R-squared & 0.821075 & & & \\
\hline Adjusted R-squared & 0.710008 & & & \\
\hline F-statistic & 10.11425 & & & \\
\hline Durbin-Watson stat & 2.183958 & & & \\
\hline
\end{tabular}

Source: Authors computation.

Table 5. Parsimonious model for electricity supply equation

\begin{tabular}{|l|l|l|l|l|}
\hline Dependent Variable: LOG(ES) & \multicolumn{5}{l|}{} \\
\hline Variable & Coefficient & Std. Error & t-Statistic & Prob. \\
\hline DLnES(-1) & 0.680066 & 0.154728 & $4.395227^{* *}$ & 0.0002 \\
\hline DP & 0.000727 & 0.001679 & $-0.432808^{*}$ & 0.6692 \\
LnTECH & 30.34707 & 13.77281 & $2.365540^{* *}$ & 0.0361 \\
LnTECH(-1) & 20.14408 & 18.20164 & $-2.498631^{* *}$ & 0.0408 \\
LnTECH(-2) & 19.65774 & 10.72641 & $-3.366753^{* *}$ & 0.0047 \\
\hline DLnGF(-2) & 0.011023 & 0.014217 & $3.775322^{* *}$ & 0.0060 \\
\hline LnPWL & -0.055607 & 0.052815 & $-2.052861^{* *}$ & 0.0033 \\
\hline LnPWL(-1) & -0.138672 & 0.052044 & $1.664513^{*}$ & 0.3138 \\
\hline
\end{tabular}




\begin{tabular}{|l|l|l|l|l|}
\hline LnPWL(-2) & -0.004003 & 0.056080 & $0.071387^{*}$ & 0.9437 \\
\hline ECM(-1) & -0.753192 & 0.000185 & $2.035448^{* *}$ & 0.0112 \\
\hline C & 1.480150 & 0.787908 & $1.878583^{*}$ & 0.0730 \\
\cline { 1 - 2 } R-squared & 0.889914 & & & \\
\cline { 1 - 2 } Adjusted R-squared & 0.806409 & & & \\
\cline { 1 - 2 } F-statistic & 26.56106 & & \\
\cline { 1 - 2 } Durbin-Watson stat & 2.073721 & & \\
\cline { 1 - 2 } & & & &
\end{tabular}

$* *=$ Significant at 5 per cent level

$*=$ Not significant at 5 per cent level.

Source: Authors computation.

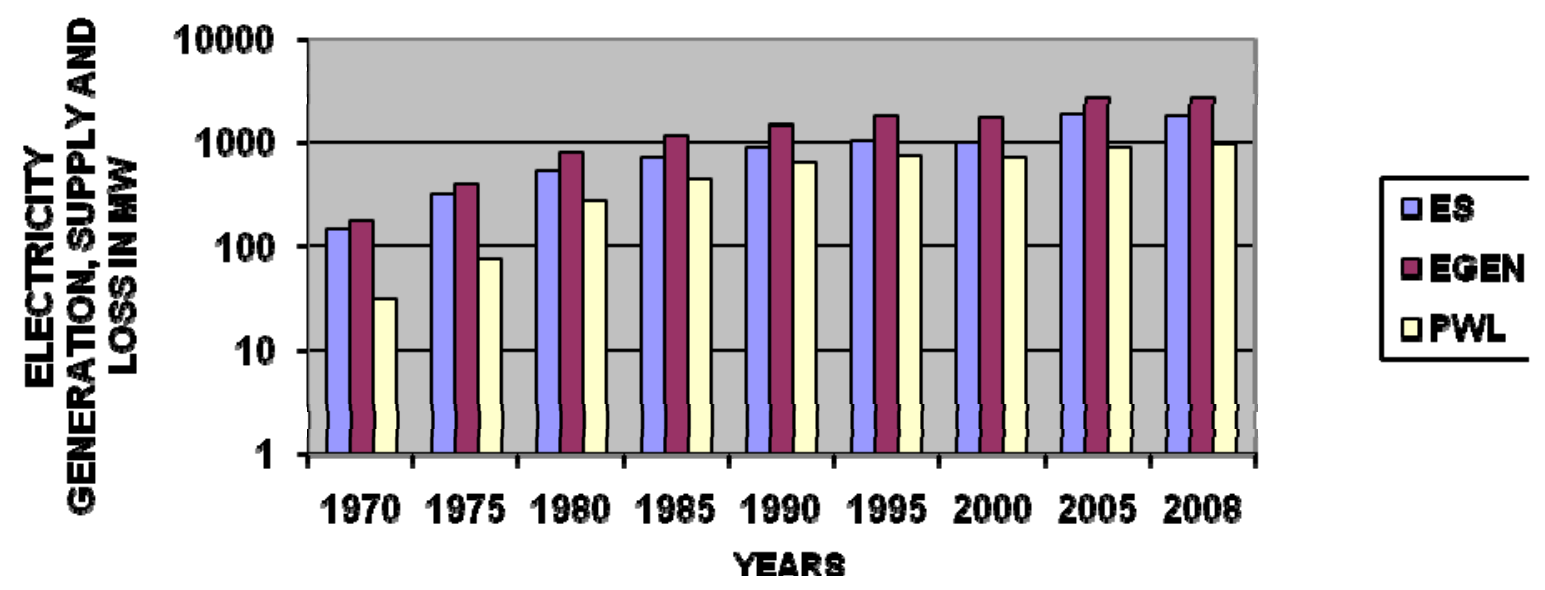

Figure 1. Electricity generation, supply and power loss in mega watts

Source: CBN Statistical bulletin 2009.

From Figure 1(see appendix), there had been a steady increase in power loss (PWL) as noted from 1970 to 2008. It would have been expected that power loss in transmission should be decreasing as generation and supply increase. But figure 1 shows that power loss in transmission is increasing at the same rate as generation and supply. An average of 900 MW is lost annually in transmission from 1970 to 2008 which is very high when compared to an average of 60-70 MW lost in most industrialized or developed countries. 